\title{
EFFECT OF DIFFERENT ORGANIC MANURES AND MEDICINAL PLANTS IN THE BIOLOGICAL CONTROL OF NEMATODES INFECTING TOMATO PLANTS
}

\author{
Yassin A. Rjoub \\ Albalqaa Applied University, Universal Collage of Alhusson, Irbid, Jordan
}

\section{ABSTRACT}

This experiment was conducted under green house conditions to evaluate the effect of cattle manure, poultry manure, neem leaf powder, White Wormwood leaf powder, Palestinian Arum leaf powder, singly and in combination, on the control of plant parasitic nematodes infecting tomato plants. Results indicated that, one month after applications, the highest decrease in the average numbers of plant parasitic nematodes was recorded with the treatments of Palestinian arum + Poultry manure (185.3 nematodes) and Neem + Poultry manure (200.3 nematodes), in comparison with the control treatment (390.7 nematode). After two months of applications, the highest decrease in the average numbers of nematodes was recorded with Neem + Poultry manure (90.3 nematodes) and Palestinian arum + farmyard manure (96.3 nematodes), in comparison with the control treatment (469.7 nematodes). Three months after applications, the highest decrease in nematodes was recorded with Palestinian arum + Poultry manure (68.3 nematodes) and Neem + Poultry manure (56.3 nematodes), in comparison with the control treatment (567.3 nematodes).The highest increase of tomato fruit yields was recorded with the nematicide Carbufuran , Neem + Poultry manure, and Neem + farmyard manure $(50.68,46.96,45.36 \%)$. Finally, it could be concluded that the application of Neem plus Poultry manure to tomato seedlings gave very good results in the control of plant parasitic nematodes, as well as, it increased the tomato yield of fruits.

Key words: Nematodes, Tomato, Biological control, Medicinal plants.

\section{INTRODUCTION}

Nematode control is essentially prevention, because once a plant is parasitized it is impossible to kill the nematode without destroying the host. The most sustainable approach to nematode control will integrate several tools and strategies, including cover crops, crop rotation, soil solarization, least-toxic pesticides, and plant varieties resistant to nematode damage. These methods work best in the context of a healthy soil environment with sufficient organic matter to support diverse populations of microorganisms. A balanced soil ecosystem will support a wide variety of biological control organisms that will help keep nematode pest populations in check. Some plants produce allelochemicals that function as nematode-antagonistic compounds, such as polythienyls, glucosinolates, cyanogenic glycosides, alkaloids, lipids, terpenoids, steroids, triterpenoids, and phenolics, among compounds from these plants e.g., castor bean, chrysanthemum, partridge pea, velvetbean, sesame, jack bean, crotalaria, sorghum-sudan, indigo, tephrosia are exuded during the growing season or released during green manure decomposition. Sunn hemp, a tropical legume, and sorghumsudan, a prolific grass plant grown for its biomass, are popular nematodesuppressive cover crops that produce the allelochemicals known as monocrotaline and dhurrin, respectively. (Chitwood, 2002; Grossman, 1988; Hackney and 
Dickerson, 1975; Quarles, 1993; Wang et al., 2002; Williams and Williams, 1990a, 1990b, 1993)

Therefore, this trail was conducted to use some materials as biological pesticides to control nematodes which also will decrease the population of other pathogenic microorganisms which participate with nematodes to cause complex diseases to vegetable crops in plastic houses.

\section{MATERIALS AND METHODS}

\section{1- Agents and treatments:}

Agents and treatments as well as the structure and rate of application was as follow in Table 1:

Table (1). Agents, structures and rate of applications.

\begin{tabular}{|c|c|}
\hline Substances & Structure and rate of application \\
\hline & $\begin{array}{l}\text { Mixture of cattle, sheep, goat dung, soil, nutrition substances, } \\
\text { applied at the rate of } 20 \mathrm{~m} 3 / \text { feddan. } \\
(500 \mathrm{~cm} 3 / \text { seedling })\end{array}$ \\
\hline Poultry manure & $\begin{array}{l}\text { Mixture of chicken refuse, soil, nutrition substances, applied at } \\
\text { the rate of } 5 \text { m3/feddan. } \\
\text { ( } 125 \mathrm{~cm} 3 / \text { seedling })\end{array}$ \\
\hline $\begin{array}{l}\text { Neem } \\
\text { leaf powder }\end{array}$ & $\begin{array}{l}\text { Neem Azadirachta indica is a medicinal plant contained } \\
\text { sesquiterpene lactones. Used as dry powder of leaves and } \\
\text { stems at the rate of } 3 \mathrm{~g} / \text { plant ( } 100 \mathrm{~kg} / \mathrm{feddan}) \\
(35 \mathrm{~g} / \text { seedling) }\end{array}$ \\
\hline $\begin{array}{l}\text { White } \\
\text { Wormwood } \\
\text { leaf powder }\end{array}$ & $\begin{array}{l}\text { Artemisia herba alba a herbal plant have strong aromas and } \\
\text { bitter tastes from terpenoids and sesquiterpene lactones, which } \\
\text { exists as an adaptation to discourage herbivory. Used as dry } \\
\text { powder of leaves and stems at the rate of } 35 \mathrm{~g} / \text { plant (100 } \\
\mathrm{kg} / \mathrm{fed} \text { ). }\end{array}$ \\
\hline $\begin{array}{l}\text { Palestinian } \\
\text { Arum } \\
\text { leaf powder }\end{array}$ & $\begin{array}{l}\text { Arum palestinian a repent plant contains Calcium oxalate and } \\
\text { some minerals and vitamins. Used as dry powder of leaves and } \\
\text { stems at the rate of } 35 \mathrm{~g} / \mathrm{plant} \text { ( } 100 \mathrm{~kg} / \mathrm{feddan}) \text {. }\end{array}$ \\
\hline Cark & $\begin{array}{l}\text { Trade Name: Carboran } 10 \% \mathrm{G} \\
\text { Common Name: Carbufuran } 10 \% \mathrm{G} \\
\text { Mole Formula: } \mathrm{C} 12 \mathrm{H} 15 \mathrm{NO} 3 \\
\text { Chemical Name: } 2, \quad 3 \text {-di hydro-2, 2-dimethyl-7-benzofuranyl } \\
\text { methyl carbamate. } \\
\text { Applied as soil treatment at the rate of } 6 \mathrm{~kg} / \text { feddan. } \\
(2 \mathrm{~g} / \text { seedling). }\end{array}$ \\
\hline
\end{tabular}

2- Effect of single and mixed applications of some materials on the control of plant parasitic nematodes:

To study the effect of 12 materials in the control of plant parasitic nematodes infecting tomato plants variety (Pritchard) under plastic house conditions $\left(25 \pm 5{ }^{\circ} \mathrm{C} \& 70 \pm 5 \%\right.$ relative humidity). Thirty-nine plots each $3 \mathrm{~m} 2$ were planted with tomato seedlings (4 weeks old) at $30 \mathrm{~cm}$ long and $90 \mathrm{~cm}$ width. Each spot was planted with 2 seedlings. Each treatment was replicated 3 times. Treatments were arranged as a randomized complete block design. 
Materials were applied at the time of planting as follows:

1- Farmyard manure

2- Poultry manure

3- Neem

4- White wormwood

5- Palestinian arum

6- Neem + Farmyard manure

7-White wormwood+ Farmyard manure

8-Palestinian arum + Farmyard manure

9- Neem + Poultry manure

10- White wormwood + Poultry manure

11- Palestinian arum + Poultry manure

12- Carbofuran

13- Control

All agricultural practices were done as usual except application of any chemicals and pesticides. Check treatment was left without any applications. Drop irrigation was established in the plastic houses, the mean average of air temperature was ranged from $22-26{ }^{\circ} \mathrm{C}$. and the relative humidity was ranged between $60-70 \%$. Seedlings were planted at the first of February 2018 and continued to the end of June, 2018, while irrigation was established under plastic houses, the mean average of air temperature was ranged from $19-23^{\circ} \mathrm{C}$. Seedlings were planted at the same time of irrigation in the plastic houses. Composite soil samples each about $1 \mathrm{~kg}$ were collected from treatments before planting and monthly to the end of the experiment. Crop of tomato fruits was recorded from each treatment as $\mathrm{kg} /$ plant. At the end of the experiment, fresh weights of plants were calculated.

\section{3-Sampling Procedures:}

Soil samples were collected from plastic houses, using a hand trowel where while the dried surfaces of soil was removed and samples were taken from the wetted rhizosphere region of the soil and transferred to the laboratory to extract nematodes and determine the population of each genus and to identify nematode genera especially plant parasitic ones.

Soil samples of about $1 \mathrm{~kg}$ were collected from the rhizosphere of growing plants by digging the soil to a depth of $15-20 \mathrm{~cm}$. From each sampling site a number of subsamples were collected and thoroughly mixed to form a composite sample, representing the whole treatment.

The collected samples were kept in polyethylene bags and sent to the laboratory for nematode extraction, numeration and identification.

\section{4-Nematode Extraction and Numeration:}

Each composite soil sample was carefully mixed, and an aliquot of 100 cm3 was processed for nematode extraction according to methods described by Southey (1970), each treatment was replicated three times. About $300-400 \mathrm{ml}$ of water were added to the soil in a glass beaker $(1000 \mathrm{ml})$ and the mixture was agitated by fingers, after few seconds the suspension was poured onto a 60 mesh-sieve and passing suspension was collected in another clean glass beaker. Materials caught on the 60 mesh-sieve were discarded, while the collected suspension was then poured onto a 200 mesh-sieve. Materials remain on the sieve were thoroughly washed by a gentle streamed of water into a $200 \mathrm{ml}$ beaker. The resulting suspension containing nematodes was then transferred to a Modified 
Baermann pan fitted with soft tissue paper for the separation of active nematodes from debris and fine soil particles. After $72 \mathrm{hrs}$, nematode water suspension was collected and concentrated to $20 \mathrm{ml}$ in a vial by using a 350 mesh-sieve. An aliquant of $1 \mathrm{ml}$ each of nematode suspensions were pipetted off, placed in a Hawksley counting slide and examined using a stereomicroscope.

Nematode counts were made 1,2, and 3 months of application, and the identification to generic level were based on morphology of the adult and larval forms, according to the description of Mai and Lyon (1975).

\section{5- Tomato fruit crops:}

The total accumulative fruit crops were calculated to the end of the experiments.

\section{6- Statistical analysis:}

All obtained data were subjected to ANOVA test using a computer program (CoStat 6.400, 2008) to determine Duncan's multiple range test and the LSD 5\% (least significant difference). In addition, Abbott's formula (1925) was used to determine the increase percentages of vegetative characters.

Reduction percentages were counted according to the formula of Henderson and Tilton (1955):

$$
\begin{aligned}
& \text { Reduction } \%= \\
& {\left[1-\left(\frac{\text { Treatment after }}{\text { Treatment before }} \times \frac{\text { Control before }}{\text { Controlafter }}\right)\right] \times 100}
\end{aligned}
$$

\section{RESULTS AND DISCUSSION}

The identification of plant parasitic nematode genera in the experimental area revealed the presence of the following genera: Pratylenchus, Helicotylenchus, Tylenchorhynchus, Meloidogyne, Pratylenchus, Xiphinema, Longidorus, and Trichodorus.
Data presented in Table (2) show the average numbers of plant parasitic nematodes infected the rhizosphere soil of tomato plants cultivated under greenhouse conditions $\left(25 \pm 5^{\circ} \mathrm{C} \& 70\right.$ $\pm 5 \%$ relative humidity) as affected by the application of leaf powders of medicinal plants singly or in combinations, in addition to the reduction percentages of nematodes.

Statistical analysis of data in Table (2) cleared that there were significant differences, in the average numbers of plant parasitic nematodes infected the rhizosphere soil of tomato plants, between control treatment and all other treatments, one, two, and three months after applications.

One month after applications, the highest decrease in the average numbers of plant parasitic nematodes infected the rhizosphere soil of tomato plants was recorded with the treatments of Palestinian Arum + Poultry manure (185.3 nematode individual / $100 \mathrm{~cm} 3$ soil) and Neem + Poultry manure (200.3 nematode individual / $100 \mathrm{~cm} 3$ soil), in comparison with the control treatment (390.7 nematode individual / $100 \mathrm{~cm} 3$ soil).

Two months after applications, the highest decrease in the average numbers of plant parasitic nematodes infected the rhizosphere soil of tomato plants was recorded with the treatments of Worm wood + Poultry manure (110.3 nematode individual / 100 cm3 soil) and Poultry manure (112.3 nematode individual / $100 \mathrm{~cm} 3$ soil), in comparison with the control treatment (469.7 nematode individual / $100 \mathrm{~cm} 3$ soil).

Three months after applications, the highest decrease in the average numbers of plant parasitic nematodes 
infected the rhizosphere soil of tomato plants was recorded with the treatments of Palestinian arum + Poultry manure (68.3 nematode individual / $100 \mathrm{~cm} 3$ soil) and Poultry manure (75.7 nematode individual / $100 \mathrm{~cm} 3$ soil), in comparison with the control treatment (567.3 nematode individual / $100 \mathrm{~cm} 3$ soil).

Data presented in Table (3) clear the effect of the application of different materials on the fruit yields of tomato plants as a result of the control of plant parasitic nematodes.

Statistical analysis of data in Table (3) cleared that there were significant differences, in the average weights of fruit yields of tomato plants, between control treatment and all other treatments.

The highest numbers in the average weights of fruit yields of tomato plants was recorded with the treatments of the nematicide.

Table (2): Average numbers of plant parasitic nematodes infecting tomato plants, 1,2, and 3 months after applications of different materials, under green house conditions

\begin{tabular}{|c|c|c|c|c|c|}
\hline \multirow[b]{2}{*}{ Treatments } & \multicolumn{4}{|c|}{ Average numbers of nematodes per $100 \mathrm{~g}$ soil } & \multirow[b]{2}{*}{$\begin{array}{l}\text { Reduction } \\
\text { percentages }\end{array}$} \\
\hline & $\begin{array}{l}\text { Pre } \\
\text { treatment }\end{array}$ & $\begin{array}{c}\text { One } \\
\text { month } \\
\text { after } \\
\text { application }\end{array}$ & $\begin{array}{l}\text { Two month } \\
\text { after } \\
\text { application }\end{array}$ & $\begin{array}{c}\text { Three } \\
\text { month after } \\
\text { application }\end{array}$ & \\
\hline Farmyard manure & $395.3 \mathrm{a}$ & $360.3 \mathrm{~b}$ & $210.0 \mathrm{~d}$ & $115.7 \mathrm{~d}$ & 82.15 \\
\hline Poultry manure & $380.3 \mathrm{~b}$ & $320.0 \mathrm{c}$ & $112.3 \mathrm{~g}$ & $75.7 \mathrm{~g}$ & 87.86 \\
\hline Neem & $378.7 \mathrm{~b}$ & $251.3 \mathrm{~b}$ & $265.0 \mathrm{~b}$ & $180.7 \mathrm{~b}$ & 70.90 \\
\hline Worm wood & $295.0 \mathrm{f}$ & $260.0 \mathrm{~d}$ & $230.0 \mathrm{c}$ & $180.0 \mathrm{~b}$ & 62.79 \\
\hline Palestinian arum & $350.7 \mathrm{c}$ & $223.0 \mathrm{e}$ & $125.3 \mathrm{f}$ & $112.3 \mathrm{~d}$ & 80.47 \\
\hline $\begin{array}{c}\text { Neem + Farmyard } \\
\text { manure }\end{array}$ & $326.7 \mathrm{e}$ & $320.0 \mathrm{c}$ & $200.0 \mathrm{~d}$ & $96.3 \mathrm{e}$ & 81.99 \\
\hline $\begin{array}{c}\text { Worm wood + } \\
\text { Farmyard manure }\end{array}$ & $349.3 \mathrm{c}$ & $241.3 d$ & $183.3 \mathrm{e}$ & $126.7 \mathrm{c}$ & 77.88 \\
\hline $\begin{array}{l}\text { Palestinian arum + } \\
\text { Farmyard manure }\end{array}$ & $289.3 \mathrm{f}$ & $200.3 \mathrm{fg}$ & 96.3 hi & $85.0 \mathrm{f}$ & 82.08 \\
\hline $\begin{array}{c}\text { Neem + Poultry } \\
\text { manure }\end{array}$ & $321.7 \mathrm{e}$ & 210.0 ef & $90.3 \mathrm{i}$ & $56.3 \mathrm{~h}$ & 89.33 \\
\hline $\begin{array}{l}\text { Worm wood + } \\
\text { Poultry manure }\end{array}$ & $365.0 \mathrm{~b}$ & 210.3 ef & $110.3 \mathrm{~g}$ & $87.7 \mathrm{f}$ & 85.35 \\
\hline $\begin{array}{c}\text { Palestinian arum + } \\
\text { Poultry manure }\end{array}$ & 333.3 de & $185.3 \mathrm{~g}$ & $125.3 \mathrm{f}$ & $68.3 \mathrm{~g}$ & 87.50 \\
\hline Carbufuran & $370.0 \mathrm{~b}$ & 210.0 ef & $103.3 \mathrm{gh}$ & $25.0 \mathrm{i}$ & 95.88 \\
\hline Control & $346.0 \mathrm{~cd}$ & $390.7 \mathrm{a}$ & $469.7 \mathrm{a}$ & $567.3 \mathrm{a}$ & - \\
\hline LSD $5 \%$ & 14.5 & 16.3 & 10.3 & 8.1 & - \\
\hline
\end{tabular}

Means in each column followed by the same letter ( $s$ ) are not significantly different at $5 \%$ level.

Carbofuran, Neem + Poultry manure, and Neem + farmyard manure 51.3, $47.746 .3 \mathrm{~kg} / 10$ plants, respectively, in comparison with the control treatment (25.3 kg / 10 plants).

The highest increase percentages of fruit yields of tomato plants was 
recorded with the treatments of the nematicide Carbofuran, Neem + Poultry manure, and Neem + Farmyard manure $50.68,46.96, \quad 45.36 \%$, respectively, in comparison with the control treatment.

Table (3): Average weights of tomato fruit yields as affected by the application of different materials, under green house conditions.

\begin{tabular}{|c|c|c|c|}
\hline Treatments & Application rates & $\begin{array}{l}\text { Average weights } \\
\text { of tomato fruits } \\
\text { per } 10 \text { plants }\end{array}$ & $\begin{array}{c}\text { Increase } \\
\text { percentages } \\
\text { of tomato fruits } \\
\%\end{array}$ \\
\hline Farmyard manure & $\left(500 \mathrm{~cm}^{3} /\right.$ seedling $)$ & 39.7 ef & 36.27 \\
\hline Poultry manure & (125 cm $\mathrm{cm}^{3}$ seedling) & $43.7 \mathrm{~cd}$ & 42.11 \\
\hline Neem & (35 g/ seedling) & $33.7 \mathrm{hi}$ & 24.93 \\
\hline White Wormwood & (35 g/ seedling) & $30.3 \mathrm{i}$ & 16.50 \\
\hline Palestinian Arum & (35 g/ seedling) & $35.0 \mathrm{gh}$ & 27.71 \\
\hline Neem + Farmyard manure & $\begin{array}{l}(35 \mathrm{~g} / \text { seedling })+ \\
\left(500 \mathrm{~cm}^{3} / \text { seedling }\right)\end{array}$ & $46.3 \mathrm{bc}$ & 45.36 \\
\hline $\begin{array}{l}\text { White Wormwood + } \\
\text { Farmyard manure }\end{array}$ & $\begin{array}{l}\text { (35 g / seedling) }+ \\
\left(500 \mathrm{~cm}^{3} / \text { seedling }\right)\end{array}$ & $37.0 \mathrm{fg}$ & 31.62 \\
\hline $\begin{array}{l}\text { Palestinian Arum } \\
\text { Farmyard manure }\end{array}$ & $\begin{array}{l}\text { (35 g / seedling) }+ \\
\left(500 \mathrm{~cm}^{3} / \text { seedling }\right)\end{array}$ & $43.0 \mathrm{~cd}$ & 41.16 \\
\hline Neem + Poultry manure & $\begin{array}{l}\text { (35 } \mathrm{g} / \text { seedling })+ \\
\left(125 \mathrm{~cm}^{3} / \text { seedling }\right)\end{array}$ & $47.7 \mathrm{~b}$ & 46.96 \\
\hline $\begin{array}{l}\text { White Wormwood + } \\
\text { Poultry manure }\end{array}$ & $\begin{array}{l}\text { (35 g/ seedling) }+ \\
\left(125 \mathrm{~cm}^{3} / \text { seedling }\right)\end{array}$ & $43.7 \mathrm{~cd}$ & 42.11 \\
\hline $\begin{array}{l}\text { Palestinian Arum + Poultry } \\
\text { manure }\end{array}$ & $\begin{array}{l}\text { (35 g/ seedling) }+ \\
\left(125 \mathrm{~cm}^{3} / \text { seedling }\right)\end{array}$ & $42.3 \mathrm{de}$ & 40.19 \\
\hline Carbofuran & (2 g/ seedling) & $51.3 \mathrm{a}$ & 50.68 \\
\hline Control & - & $25.3 \mathrm{j}$ & - \\
\hline LSD $5 \%$ & & 3.2 & \\
\hline
\end{tabular}

Means in each column followed by the same letter (s) are not significantly different at $5 \%$ level.

Finally, it could be concluded that the application of Neem plus Poultry manure to tomato seedlings gave very good results in the control of plant parasitic nematodes, as well as, it increased the tomato yield of fruits.

The obtained results are in harmony with the experiments conducted by ElRab (2000) who controlled Meloidogyne incognita using Damsis plants dry matter (Ambrosia martimala L.) as natural material on cucumber in Egypt. Ibrahim and Ibrahim (2000) evaluated marine algae in the control of Meloidogyne incognita on common bean. Bari, et al. (2004) who used organic soil amendments to control root-knot nematode of Brinjal. Jung, and Han (2004) studied the biological control of the northern root-knot nematode, Meloidogyne hapla using cultural method and biological agents, i.e. Bacillus thuringiensis (Bt), Paecilomyces lilacinus and plant extract (Huhjuni), in the fields of Codonopsis lanceolata. El-Gindi et al. (2005) evaluated the efficacy of the aqueous extracts of cabbage, dill, fennel, Sesbania aculeata, Washingtonia filifera, Pimpinella anisum and Thymus vulgaris in controlling the root-knot nematode, $M$. incognita. El-Nagdi (2006) studied the 
management of the root-knot nematode, Meloidogyne incognita infecting cowpea as influenced by intercropping with sea ambrosia, jojoba and marigold as antagonistic plants. Radwan et al. (2007) compared the nematicidal potentials of dried leaves of five plant species against Meloidogyne incognita infecting tomato. Recently, Sweelam et al., 2019 successively controlled citrus nematode using three bioagents under field conditions.

\section{REFERENCES}

Abbott, W.S. (1925). A method of computing the effectiveness of an insecticide. Journal of Economic Entomology (18): 265-267.

Bari, M. A.; M. I. Faruk; M. L. Rahman and M. R. Ali (2004). Effect of organic soil amendments and nematicide on root-knot nematode of brinjal. Bangladesh Journal of Plant Pathology. 20: 27-30.

Chitwood, D. J. (2002). Phytochemical based strategies for nematode control. Annual Review of Phytopathology. Vol. 40. p. 221249.

CoStat 6.400. (2008). Statistical CoHort Software program, Copyright (C) 1998- 2008 CoHort Software 798 Lighthouse Ave. PMB 320 Monterey CA, 93940 USA.

El-Gindi, A. Y.; H. A. Osman; M. M. A. Youseef; H. H. Ameen and A. M. Lashein (2005). Evaluation of the nematicidal effects of some organic amendments, biofertilizers and intercropped marigold, Tagetes erecta plant on the root knot nematode, Meloidogyne incognita infected cowpea plants. Bulletin of the National Research Centre Cairo. 30: 307-315.
El-Nagdi, W. M. A. (2006). Management of the root-knot nematode, Meloidogyne incognita infecting cowpea as influenced by intercropping with sea ambrosia, jojoba and marigold as antagonistic plants. Pakistan Journal of Nematology. 24: 65-74.

El-Rab, S. M. G. (2000). Studies on the effect of Damsis sp. dry matter (Ambrosia martimala L.) as natural material to control nematodes of plastic-houses cucumber in Egypt. Egyptian Journal of Horticulture. 27: 373-383.

Grossman, J. (1988). Research notes: New directions in nematode control. The IPM Practitioner. February. p.1- 4.

Hackney, R.W., and O. J. Dickerson (1975). Marigold, castor bean, and chrysanthemum as controls of Meloidogyne incognita and Pratylenchus alleni. Journal Nematology. Vol. 7, (1): 84-90.

Henderson, C. F. and W. Tilton (1955). Tests with acaricides against the brown wheat mite. Journal of Economic Entomology, 48: 157161.

Ibrahim, A. A. M. and I. K. A. Ibrahim (2000). Evaluation of non-chemical treatments in the control of Meloidogyne incognita on common bean. Pakistan Journal of Nematology. 18: 51-57.

Jung, D. and S. Han (2004). Biological control of the northern root-knot nematode, Meloidogyne hapla in the fields of Codonopsis lanceolata. Korean Journal of Applied Entomology. 43: 27-34.

Mai, W.F. and H. H. Lyon (1975). Plant-Parasitic Nematodes: A Pictorial Key to Genera (Comstock 
Books) Publisher: Peter G. Mullin, Cornell University Press; 5 Sub edition , 277 pp.

Quarles, W. (1993). Rapeseed green manure controls nematodes. The IPM Practitioner. April. p. 15.

Radwan, M. A.; E. K. El-Maadawy and M. M. Abu-Elamayem (2007). Comparison of the nematicidal potentials of dried leaves of five plant species against Meloidogyne incognita infecting tomato. Nematologia Mediterranea. 35: 8184.

Southey, J. F. (1970). Laboratory Methods for Work with Plant and Soil Nematodes. Ministry of Agriculture, Fishers and Food. Technical Bulletin 2: 5 th ed., 148 pp.

Sweelam, M.E.; M. S. Abokorah, Safaa M. Abo Taka and Seham M. AbdEllatief (2019). Biological control of the citrus nematode, Tylenchulus semipenetrans attacking Citrus sienensis Naval orange trees. Menoufia Journal of Plant Protection 4:179-188.

Wang, K. H., B. S. Sipes, and D. P. Schmitt (2002). Suppression of Rotylenchulus reniformis by Crotalaria juncea, Brassica napus, and Target erecta. Nematropica. Vol. 31. p. 237-251.

Williams, G. and P. Williams (1990a). Sesame residues vs. harmful nematodes. Hort. Ideas. March. p. 35.

Williams, G. and P. Williams (1990b). Some plant nutrients repel harmful nematodes. Hort. Ideas. June. p. 63.

Williams, G. and P. Williams (1993). Wheat vs. nematodes causing peach tree short life. Hort. Ideas. July. p. 76. 